\title{
Innovative Target Therapies Are Able to Block the Inflammation Associated with Dysfunction of the Cholesterol Biosynthesis Pathway
}

\author{
Annalisa Marcuzzi ${ }^{1} *$, Elisa Piscianz ${ }^{2}$, Claudia Loganes ${ }^{1}$, Liza Vecchi Brumatti ${ }^{2}$, \\ Alessandra Knowles ${ }^{2}$, Sabrine Bilel ${ }^{3}$, Alberto Tommasini ${ }^{2}$, Roberta Bortul ${ }^{1}$ and \\ Marina Zweyer ${ }^{1}$ \\ Received: 17 November 2015; Accepted: 24 December 2015; Published: 30 December 2015 \\ Academic Editors: Ge Zhang and Aiping Lu \\ 1 Department of Medicine, Surgery and Health Sciences, University of Trieste, Piazzale Europa 1, \\ Trieste 34128, Italy; claudia.loganes@gmail.com (C.L.); bortul@univ.trieste.it (R.B.); zweyer@units.it (M.Z.) \\ 2 Institute for Maternal and Child Health-IRCCS "Burlo Garofolo", via dell'Istria, 65/1, Trieste 34137, Italy; \\ elisa.piscianz@gmail.com (E.P.); liza.vecchibrumatti@burlo.trieste.it (L.V.B.); \\ alessandra.knowles@burlo.trieste.it (A.K.); alberto.tommasini@burlo.trieste.it (A.T.) \\ 3 Cluster in Biomedicine (CBM scrl), Trieste 34128, Italy; sabrouna14@live.com \\ * Correspondence: annalisa.marcuzzi@burlo.trieste.it; Tel.: +39-040-378-5422
}

\begin{abstract}
The cholesterol pathway is an essential biochemical process aimed at the synthesis of bioactive molecules involved in multiple crucial cellular functions. The end products of this pathway are sterols, such as cholesterol, which are essential components of cell membranes, precursors of steroid hormones, bile acids and other molecules such as ubiquinone. Several diseases are caused by defects in this metabolic pathway: the most severe forms of which cause neurological involvement (psychomotor retardation and cerebellar ataxia) as a result of a variety of cellular impairments, including mitochondrial dysfunction. These pathologies are induced by convergent mechanisms in which the mitochondrial unit plays a pivotal role contributing to defective apoptosis, autophagy and mitophagy processes. Unraveling these mechanisms would contribute to the development of effective drug treatments for these disorders. In addition, the development of biochemical models could have a substantial impact on the understanding of the mechanism of action of drugs that act on this pathway in multifactor disorders. In this review we will focus in particular on inhibitors of cholesterol synthesis, mitochondria-targeted drugs and inhibitors of the inflammasome.
\end{abstract}

Keywords: cholesterol; mitochondria; apoptosis; autophagy; inflammasome

\section{The Cholesterol Pathway: A Pleiotropic Biochemical System}

The cholesterol pathway (CP), also called the mevalonate pathway, is a crucial metabolic process that leads to the synthesis of cholesterol and other biomolecules such as steroidal hormones and isoprenoids. These essential bioactive molecules play an important role in multiple cellular processes, including intracellular signaling, gene expression, protein modification, cell growth/differentiation, cytoskeletal dynamics and stability, mitochondrial function and cell membrane structure [1,2].

The $\mathrm{CP}$ is promoted by a molecule of acetyl-CoA and its thiolase (Acetoacetyl-CoA), using the 3-hydroxy-3-methylglutaryl-Coenzyme A (HMG-CoA) synthase, to synthesize HMG-CoA. HMG-CoA reductase (HMGCR) then converts HMG-CoA to mevalonate (MVA), which is further metabolized to Isopentenyl-5-pyrophosphate (IPP) and its isomer Dimethyllallyl-pyrophosphate (DMAPP). At this point, Farnesyl pyrophosphate (FPP) synthase catalyzes a sequential reaction to generate mevalonate-derived isoprenoids, such as FPP and geranylgeranyl pyrophosphate (GGPP) [1-3]. 
For the synthesis of cholesterol, two molecules of FPP are converted by squalene synthase to the linear hydrocarbon molecule squalene, which is cyclized to the first sterol intermediate, lanosterol, and then converted, through a series of reactions, to cholesterol.

FPP is also one of the precursors of important metabolites such as dolichols, ubiquinones (Coenzyme Q), and carotenoids. These molecules are required for protein $\mathrm{N}$-glycosylation (dolichols), mitochondrial electron transport chain function (ubiquinone), and free radical scavenging [1].

\section{HMG-CoA Reductase Controls the Cholesterol Pathway}

The cholesterol pathway is essential for several cell functions. The regulation of this biochemical process has been intensely investigated and, in particular, the role of HMGCR which is the rate-controlling enzyme of cholesterol biosynthesis. This enzyme, ubiquitously expressed in all cells, is highly regulated and is controlled by a variety of mechanisms [4]. One of these is the negative feedback, a multivalent process by which cholesterol and isoprenoid products act as inhibitors of the reductase inducing its degradation from the membranes of the endoplasmic reticulum (ER) [5]. Furthermore, sterols and non-sterol metabolites control the transcription and the translation of HMGCR by reducing the amount of mRNA in response to increased levels of cholesterol [6].

In addition to the complex feedback mechanism, HMGR controls cholesterol levels through cross-regulation: this process is employed when the catalytic domain of HMGCR is inactivated through phosphorylation by an adenosine monophosphate-dependent kinase that alters the enzyme's kinetic properties. It also occurs in response to invading pathogens or toxins that cause increases in HMGR mRNA levels and, thus, higher enzyme activity [7].

The regulation of HMGR is necessary for appropriate cholesterol synthesis. Defects in this enzyme lead to the development of inflammatory disorders [8] and diseases such as hypercholesterolemia [9]. Recent studies have proven that genetic errors can cause mutations in enzymes involved in the cholesterol cascade [10]; further investigations are necessary to determine the link between mutated enzymes and inflammatory phenotypes, in order to develop new therapies blocking the cholesterol damage in its early stages.

\section{Diseases Linked to the Deregulation of the CP}

Deregulation of the $\mathrm{CP}$ causes diseases that are severe and mostly monogenic. Among these, the mevalonate kinase deficiency (MKD) is a rare autosomal recessive disease caused by a blockade of the CP [11,12]. A defect in the pre-squalene activity of mevalonate kinase (MK, encoded by the mevalonate kinase gene, $M V K$ ) induces periodic fever syndromes, with different degrees of severity depending on the residual activity of mevalonate kinase: the autoinflammatory hyper immunoglobulinemia D (MIM 260920) is characterized by a $1 \%-8 \%$ residual MK activity, while in mevalonic aciduria (MIM 610377) MK level activity is undetectable [13,14].

There are several other disorders: Smith-Lemli-Opitz syndrome (MIM 270400), Conradi-Hünermann-Happle syndrome (MIM 302960) congenital hemidysplasia with ichthyosiform erythroderma and limb defects (CHILD, MIM 308050), and at least three extremely rare autosomal recessive disorders, Greenberg skeletal dysplasia (MIM 215140), lathosterolosis (MIM 607330) and desmosterolosis (MIM 602398). These syndromes show significant clinical overlap distinguished by physical and behavioral abnormalities, including nervous system dysfunctions with different degrees of severity. [10] (Table 1). 
Table 1. Diseases involved in the deregulation of cholesterol pathway.

\begin{tabular}{|c|c|c|c|c|c|c|}
\hline Disease/Syndrome & MIM & Genetics & Gene(s) Involved & Protein Involved & Molecular Features & Main Clinical Features \\
\hline $\begin{array}{c}\text { Mevalonate Kinase } \\
\text { Deficiency (MKD) }{ }^{\ddagger} \\
{[15,16]}\end{array}$ & $\begin{array}{l}\# 260920 \\
\# 610377\end{array}$ & $\begin{array}{l}\text { Autosomal } \\
\text { recessive }\end{array}$ & $M V K$ & Mevalonate kinase & $\begin{array}{c}\text { Accumulation of mevalonic acid in } \\
\text { urine and plasma }\end{array}$ & $\begin{array}{l}\text { Elevated serum IgD/IgA, periodic fever, } \\
\text { vomiting, diarrhea, psychomotor } \\
\text { retardation, developmental delay, } \\
\text { cerebellar and cerebral atrophy }\end{array}$ \\
\hline $\begin{array}{c}\text { Smith Lemli Opitz } \\
\text { Syndrome (SLOS) } \\
{[17-20]}\end{array}$ & \#270400 & $\begin{array}{l}\text { Autosomal } \\
\text { recessive }\end{array}$ & DHCR7 & $\begin{array}{l}\text { 7-dehydrocholesterol } \\
\text { reductase }\end{array}$ & $\begin{array}{l}\text { Low cholesterol levels, } \\
\text { accumulation of 7-DHC }\end{array}$ & $\begin{array}{l}\text { Failure to thrive, microcephaly, } \\
\text { micrognathia, ambiguous genitalia, limb } \\
\text { shortening, polydactyly, mental retardation }\end{array}$ \\
\hline $\begin{array}{l}\text { Conradi-Hunermann- } \\
\text { Happle }[19,21]\end{array}$ & \#302960 & $\begin{array}{l}\text { X-linked } \\
\text { dominant }\end{array}$ & EBP & Sterol- $\Delta 8-\Delta 7$-isomerase & $\begin{array}{c}\text { Increased levels of } \\
\text { 8-dehydrocholesterol and } \\
\text { 8(9)-cholestenol } \\
\end{array}$ & $\begin{array}{l}\text { Growth deficiency, asymmetric limb } \\
\text { shortening, mental retardation, } \\
\text { ventriculomegaly }\end{array}$ \\
\hline $\begin{array}{l}\text { CHILD syndrome } \\
{[19,22,23]}\end{array}$ & \#308050 & $\begin{array}{l}\text { X-linked } \\
\text { dominant }\end{array}$ & NSDHL & $\begin{array}{l}\text { Part of the C-4 sterol } \\
\text { demethylase protein } \\
\text { complex }\end{array}$ & $\begin{array}{l}\text { Increased levels of } \\
\text { 8-dehydrocholesterol and } \\
\text { 8(9)-cholestenol }\end{array}$ & $\begin{array}{c}\text { Prenatal growth deficiency, hearing loss, } \\
\text { unilateral distribution of abnormalities, skin } \\
\text { lesions, erythema, severe skeletal } \\
\text { abnormalities }\end{array}$ \\
\hline $\begin{array}{l}\text { Greenberg skeletal } \\
\text { dysplasia }[19,24]\end{array}$ & \#215140 & $\begin{array}{l}\text { Autosomal } \\
\text { recessive }\end{array}$ & $L B R$ & $\begin{array}{l}\text { 3ß-hydroxysteroid- } \\
\Delta 14 \text {-reductase }\end{array}$ & $\begin{array}{l}\text { Elevated cholesta-8,14-dien-3- } \beta \text {-ol in } \\
\text { cultured fibroblasts and } \\
\text { cholesta-8,14,24-trien- } 3 \beta \text {-ol in cartilage }\end{array}$ & $\begin{array}{l}\text { Hydrops-ectopic calcification-moth-eaten } \\
\text { (HEM) skeletal dysplasia, fetal death }\end{array}$ \\
\hline $\begin{array}{l}\text { Lathosterolosis } \\
\qquad[19,25]\end{array}$ & \#607330 & $\begin{array}{l}\text { Autosomal } \\
\text { recessive }\end{array}$ & $S C 5 D L$ & $\begin{array}{l}\text { 3ß-hydroxysteroid- } \\
\Delta 5 \text {-desaturase }\end{array}$ & $\begin{array}{c}\text { Increased levels of lathosterol in } \\
\text { plasma and cultured fibroblast; } \\
\text { absent 7-dehydrocholesterol, } \\
\text { normal cholesterol }\end{array}$ & $\begin{array}{l}\text { Microcephaly, polysyndactyly, colestatic } \\
\text { liver disease, conductive deafness, severe } \\
\text { psychomotor retardation }\end{array}$ \\
\hline $\begin{array}{l}\text { Desmosterolosis } \\
{[19,26-28]}\end{array}$ & \#602398 & $\begin{array}{l}\text { Autosomal } \\
\text { recessive }\end{array}$ & DHCR24 & $\begin{array}{l}\text { 3ß-hydroxysterol- } \\
\Delta 24 \text {-reductase }\end{array}$ & $\begin{array}{l}\text { Accumulations of desmosterol in } \\
\text { plasma, kidney, liver, brain }\end{array}$ & $\begin{array}{l}\text { Failure to thrive, microcephaly, anomalous } \\
\text { pulmonary venous drainage, ambiguous } \\
\text { genitalia, short limbs, generalized } \\
\text { osteosclerosis, delayed psychomotor } \\
\text { development, severe spasticity }\end{array}$ \\
\hline
\end{tabular}

$\ddagger$ Table 1. List of disorders triggered by alterations on cholesterol pathway. Mutations in the MVK gene cause MKD that range from Hyper-IgD syndrome to Mevalonic aciduria

depending on the type and severity of the mutations. 


\section{Convergent Pathogenic Mechanisms on Deregulation of the Cholesterol Pathway}

Despite progress in the understanding of the genetic causes that determine a number of pathologies associated with the deregulation of the $\mathrm{CP}$, effective and definitive drug treatments are not always identifiable [20]. Defects in the mevalonate pathway lead to the activation of an inflammatory process and of cellular mechanisms such as programmed cell death linked to mitochondrial damage, autophagy and mitophagy (Figure 1).

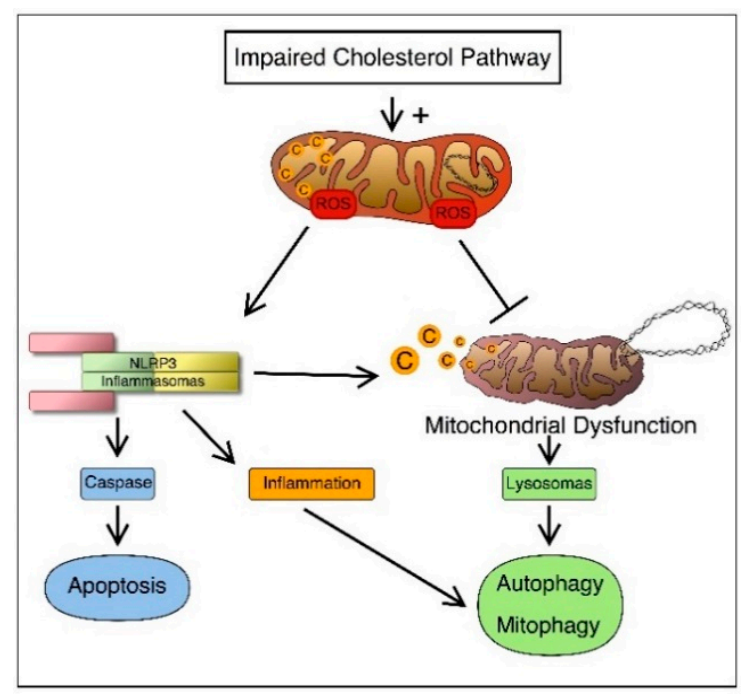

Figure 1. Connection between cholesterol disorders and inflammation. Once the cholesterol pathway is impaired, it can induce activation of the inflammosome and trigger cell apoptosis. On the other hand, production of (reactive oxygen species) ROS causes defective autophagy and/or mitophagy of damaged cells and organelles and this can further lead to NLRP3 (inflammosome) activation.

\subsection{Inflammatory Mechanisms}

The deregulation of the $\mathrm{CP}$ implies the activation of an inflammatory process by specific multiproteins, called inflammasomes [29]. Inflammasomes, described by Martinon and colleagues [30], are large molecular platforms, specialized in recognizing danger signals and in instructing the general defense mechanisms of the innate immune system [30-32]. To date, a number of inflammasomes have been clearly identified [33]: Nucleotide-binding oligomerization domain, Leucine rich Repeat and Pyrin domain containing (NLRP)1 [34], NLRP2 [35], NLRP3 [36], NLRP6 [37], NLRP7 [38], NLRP12 [39], NLR apoptosis inhibitory protein(NAIP)/NLR family, CARD-containing 4 (NLRC4) NAIP/NLRC4 [40]. The NLRP3 protein, in particular, is the best characterized component in the inflammasome platform and has been shown to be implicated in the development of chronic diseases. NLRP3, which is a crucial interface between metabolism and inflammation [41], is induced by a wide spectrum of molecules through mechanisms that have not, as yet, been fully understood.

A variety of models have been proposed to explain the main pathway of activation of NLRP3: there are interesting data showing a crucial involvement of reactive oxygen species (ROS), produced by damaged mitochondria [42]. However, the mechanism underlying the role of ROS in priming NLRP3 remains unclear [43]. Another model, designed by Hornung and colleagues, suggests that the NLRP3 inflammasome could be triggered by phagolysosomal destabilization and lysosomal damage: this "endogenous danger signal" represents for the immune system the cause activing the inflammasome [44].

In the innate immune response, an abnormal synthesis of ROS could be associated with decreased bioavailability of nitric oxide (NO), which is a major indicator of NLRP3 activation. Indeed, the 
inhibition of NLRP3 activation by NO is known to be one of the mechanisms of tissue protection by ischemic preconditioning [45].

ROS and NO have been proposed as triggers of mitochondrial dysfunction [46-48], and data in the literature have shown that cardiovascular disorders [49] and metabolic syndromes that are related to cholesterol deregulation are associated with mitochondrial damage [50-55].

Several recent data have shown that autophagy [56], and in particular mitophagy, are key links between inflammasome ROS and mitochondrial dysfunction [57,58] (Figure 2).

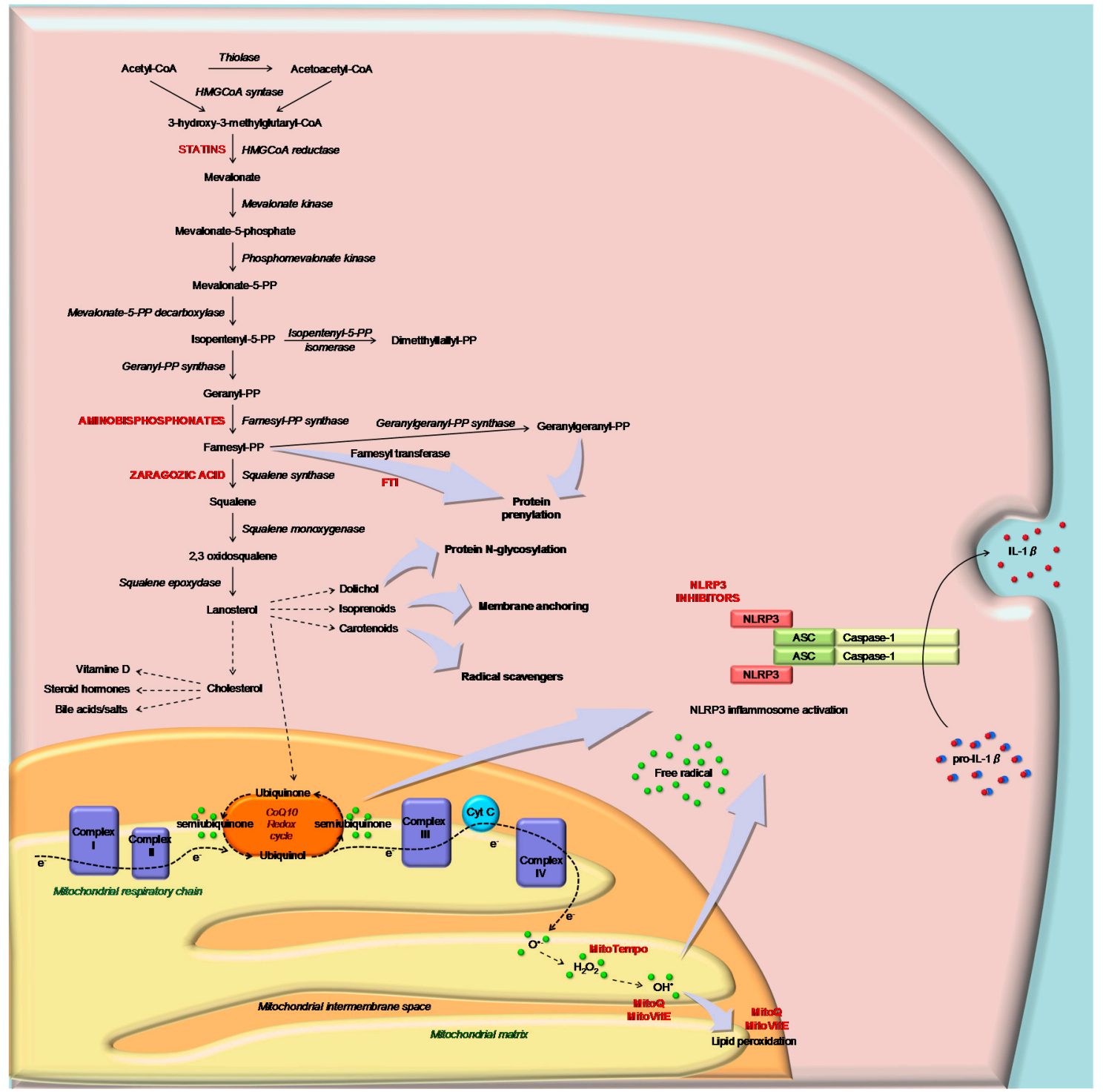

Figure 2. Schematic representation of the cholesterol pathway and of the mediation of sterol metabolites (ubiquinone) in mitochondrial respiratory function (Complex I-IV) in response to the inflammation signal. Inhibitors of CP and MTAse (as MitoQ) are indicated in capital and red characters: statins, aminobisphosphonate, squalene synthase and farnesyltransferase inhibitors. The block of $\mathrm{CP}$ leads to the activation of the NLRP3 inflammasome and consequently IL-1 $\beta$ through mitochondrial signals.

\subsection{Programmed Cell Death}

Programmed cell death or apoptosis is a homeostatic process that maintains cell populations in tissues and acts as a defense mechanism against intracellular damage caused by infection or oxidative stress. This mechanism is essential for optimal cell function and for the development of immune 
and hormonal systems [59]. Defects of apoptosis cause severe diseases such as cancer, Alzheimer's, Parkinson's and autoimmune conditions [59]. Programmed cell death, linked to an inflammatory response by the NLRP3 inflammasome, is triggered by the mitochondrial oxidative stress induced by an increase of ROS, and is followed by the apoptosis mechanism initiated by caspases $[60,61]$. The mitochondria play a central role in activating and controlling cell death mechanisms through caspase activity [60]. Our studies on MKD pathogenesis confirm that CP deregulation induces programmed cell death via mitochondrial signals, especially in neurological areas $[62,63]$.

\subsection{Autophagy and Mitophagy}

Autophagy is a catabolic process with multiple physiological functions, which acts primarily as a protective mechanism to prevent cell death. A specific type of autophagy, called mitophagy, is designed to ensure the integrity of healthy mitochondria and the removal of damaged intracellular structures $[64,65]$, preventing the accumulation of toxic mitochondrial products. The impairment of this mechanism contributes to the accumulation of ROS and to the synthesis of pro-inflammatory molecules that trigger programmed cell death. In addition to this, the abnormal biosynthesis of ROS supports a hyper-activation of the inflammatory pathways, e.g., though the NLRP3 inflammasome [66].

Low levels of activation of mitophagy may be involved in the pathogenesis of common human disorders such as Parkinson disease, diabetes, Alzheimer's disease and some forms of cancer $[67,68]$.

Understanding the molecular mechanism of mitophagy is, therefore, of crucial importance to explain its pivotal role in cellular homeostasis and to comprehend how altered "mitodynamics", (e.g., aberrant mitochondrial trafficking, modified interorganellar communication, and impaired mitochondrial quality control) may contribute to the onset of numerous diseases, from inborn errors of cholesterol biosynthesis to adult-onset neurodegenerative diseases, cancer, cardiovascular disorders, and infectious/inflammatory conditions, as well as metabolic derangements [69].

Furthermore, impaired autophagy, controlled by multiple pathways including protein isoprenylation, has been identified as one of the causes of the pathogenesis of SLOS [70], due to inefficient clearance of defective mitochondria. Similarly, in the pathogenesis of MKD, the cumulative effect of mitochondrial deregulation triggers the activation of NLRP3 and, consequently, the biosynthesis of pro-inflammatory cytokines that amplify the inflammation system [71-73].

\section{Innovative Target Therapies Counteracting Inflammation Caused by Cholesterol Dysfunctions}

In the light of the pathogenic mechanisms of $\mathrm{CP}$ deregulation, the potential therapeutic targets are both at pathway level (activation of NLRP3) and at molecular level (mitochondria and inflammasome) (Figure 2).

\subsection{Inhibitors of Cholesterol Synthesis}

The cholesterol pathway cascade is regulated by, among others, drugs such as statins (mycotoxins used to lower cholesterol levels), and bisphosphonates, used to treat various bone-degenerative diseases, including osteoporosis. These two agents, which are widely used in clinical practice for their structural resemblance to substrates within the pathway, can inhibit mevalonate synthesis (statins) or mevalonate downstream metabolism (bisphosphonates), leading to reduced formation of the isoprenoids FPP and GGPP [73,74].

The statins are a class of drugs similar to HMG-CoA in chemical structure that inhibits HMGCR, binding competitively to the active site of the enzyme. This competition reduces mevalonate biosynthesis and slows down the subsequent serial steps to produce cholesterol. According to Williams (2002), statins have greater affinity for HMGCR than HMG-CoA, therefore they are particularly efficient in controlling the production of excessive levels of cellular cholesterol [75]. Depending on dosage and type, statins display differential capacity to inhibit the mevalonate pathway and to prevent coronary 
and atherosclerosis complications [76]. For all these reasons, they are considered the "gold standard" for metabolic prevention of coronary heart diseases [77].

Statins are divided into two categories based on their molecular structure and chemistry: natural statins, such as lovastatin, simvastatin, and pravastatin, and synthetic statins, such as fluvastatin, cerivastatin, atorvastatin, and rosuvastatin [78].

The chemical composition influences the pharmacological properties of these drugs, affecting, for example, their affinity for the enzyme HMGCR, their systemic availability and their metabolism/excretion pathways [79].

A variety of combinations of statins with other agents, such as ezetimibe/simvastatin, are available on the pharmaceutical market [80].

Despite the widespread use and high safety profile of statins, recent studies have produced controversial data regarding the side effects of these drugs in particular myopathy and rhabdomyolysis [81,82]. Indeed, a recent observation has suggested that these adverse clinical effects may be caused by the mitochondrial dysfunction caused by statins [82]. According to this study, these drugs are able to promote mitochondrial permeability transient pore opening and generate apoptotic proteins, but no changes in HMGCR activities have been noted. However, because of the contradictory results and interpretations in literature, further studies are necessary to verify this hypothesis.

Finally, Izadpanah proposed a very fitting theory on these adverse clinical effects, suggesting that statins play a role in inflammation pleiotropy through stem cells: the positive effect is supported by the capacity of mesenchymal stem cells to differentiate into macrophages capable of reducing inflammation, while the negative effect could be determined by an increase in cellular senescence and apoptosis markers [83].

Bisphosphonates (BPs) are another family of drugs that act on the CP: they are currently employed to treat pathological conditions characterized by osteoclast-mediated bone loss, due to osteoporosis and other metabolic bone diseases (osteolytic bone metastasis, hypercalcemia and Paget's disease). BPs have the ability to inhibit bone digestion and resorption by concentrating bone phosphates and inhibiting osteoclast function and viability, thereby slowing down bone loss [84]. They are chemically stable analogs of pyrophosphates and compete with the analogue portion of the isoprenoid diphosphate intermediates of the mevalonate pathway. The impact of BPs on the CP is mainly due to their pyrophosphate-like structure, which enables them to bind to, and inhibit, key isoprenoid biosynthetic enzymes, such as farnesylpyrophosphate synthase (FPPS). The inhibition caused by the structure of BPs prevents the post-translational prenylation of various Guanosine-5'-Triphosphate (GTP)-binding proteins, not only in osteoclast, but also in blood cells, leading to an impairment of the various cellular functions these proteins modulate $[85,86]$.

BPs can be divided into two groups, nitrogen-containing ( $N$-containing) and non- $N$-containing BPs (or pyrophosphate-resembling BPs), based on their different mechanism of action and cell effects $[73,74]$.

The former class has become available more recently and is more powerful. It includes alendronate, pamidronate, risedronate, ibandronate and zoledronate and interferes with the mevalonate pathway by blocking FPPS. The second group, which includes etidronate and clodronate, interferes with adenosine triphosphate (ATP)-dependent intracellular pathways: the non- $N$-containing BPs are metabolically incorporated into nonhydrolyzable ATP analogues that disturb mitochondrial activity and inhibit ATP-dependent enzymes [87-89].

Also in the case of BPs there are data in the literature describing effects that are exactly opposite to those illustrated above [90]. The main side effects related to the use of these drugs are the following: renal toxicity [91,92] and acute-phase reactions (related specially to zoledronic acid) [93-97], gastrointestinal toxicity (associated to oral agents as clodronate and ibandronate) [98], and osteonecrosis of the jaw as an adverse effect of the aminobisphophonate therapy in patients whose immune system is already compromised [99]. 
In addition, a number of plant and fungal derived isoprenoids and inhibitors, introduced in various amounts through the diet, are able to modulate the CP. For example, natural isoprenoid compounds, such as geraniol, menthol, farnesol, profoundly affect MP regulation, as also do squalene synthase inhibitors (zaragozic acid, ZAA) $[100,101]$ and inhibitors of farnesyltransferase (manumycin A, Tipifarnib) [102,103].

\subsection{Mitochondrial-Target Anti-Oxidants}

The drugs that belong to the Mitochondrial-Target Anti-oxidants (MTAs) family are studied for their anti-oxidant activity and mitochondrial protection properties, and are therefore good candidate molecules to contrast oxidative stress caused by cholesterol deregulation [104]. MTAs are mitochondria-targeted drugs several hundred-fold more potent at preventing mitochondrial oxidative damage than untargeted antioxidants [90]. Once accumulated in the mitochondria, MTAs are able to inhibit selected steps along the pathway of activation of programmed cell death $[105,106]$. The compounds that belong to the MTAs family are MitoQ, Mitotempo and MitoVitE. MitoQ, in particular, is a promising antioxidant biomolecule that has been shown to protect mitochondria from various types of oxidative damage by decreasing ROS production [106-119].

The antioxidant component of MitoQ is ubiquinone, the same bioactive molecule found in Coenzyme Q10 [108].

MitoQ, positively charged with a lipophilic cation, is able to penetrate the biological membranes and accumulate selectively in the mitochondria, within the negative mitochondrial matrix [119]. The mitochondrial respiratory chain rapidly reduces MitoQ ubiquinone to its active ubiquinol form, MitoQuinol, which acts as antioxidant molecule and mobile electron donor [107,119]. In particular, ubiquinol decreases local oxidative damage, by donating a hydrogen atom to radical species formed during lipid peroxidation [120-122].

After neutralizing a free radical or ROS, the ubiquinol form is converted to ubiquinone, which is subsequently converted back to the active ubiquinol form [108,123], with restored antioxidant function.

Recently, the mitochondrial effects of MitoQ have been tested in several in vitro models demonstrating that this Mitochondrial-Target drug can reduce free radicals and oxidative damage, maintaining mitochondrial function and preventing cell death caused by endogenous oxidative stress $[106,111,124,125]$.

The MitoQ antioxidant mechanism may be due to the inhibition of lipid peroxidation in the mitochondrial inner membrane, but further studies are necessary to define the specific mechanism of action of this drug in preventing mitochondrial damage [126].

Mito $Q$ is already being studied as potential treatment for neurodegenerative diseases such as Alzheimer's disease and ischaemia-reperfusion injury, as well as other ageing-related dysfunctions [107].

Potentially therapeutic concentration of MitoQ could be delivered to mitochondria in vivo through the oral administration of well-tolerated doses of the drug [127].

MitoQ has been shown to decrease mitochondrial damage even at high doses in rats, without side effects [128]. Data in the literature have provided robust evidence to support the testing of MTAs in preclinical trials using neurodegenerative disease cell and mouse models, as well as on Alzheimer's patients.

The use of mitochondria-targeted peptides has also been shown to be effective in treating/reducing hypercholesterolemia in an animal model of acute kidney injury, in which renal injuries appeared to be alleviated after peptide treatment [129]. Data in literature confirm that several diseases, including cardiovascular and neurodegenerative diseases, insulin resistance and diabetes as well as age-related cancers, bear a common relationship to mitochondrial damage; this would support the hypothesis of a pivotal role for MTAs [130]. 


\subsection{NLRP3 Inhibitors}

Although this issue is still controversial, some data link the CP to the NLRP3 inflammasome. MKD, for example, is associated with an autoinflammatory phenotype which is probably linked to reduced protein prenylation and/or increased mitochondrial damage. Whatever the mechanism involved, autoinflammation is associated with increased activation of NLRP3 and Caspase-1. Thus, inhibition of NLRP3 may deserve to be further investigated for its potential to deal with inflammatory phenomena related to $\mathrm{CP}$ dysfunction. Over the past 10 years, a growing body of data has been collected regarding the function of NLRs, which is crucial for the identification of new therapeutic opportunities using small molecule inhibitors [130,131].

A new class of small molecule inhibitors of NLRP3 has recently been discovered. Coll and colleagues have described an innovative compound, called MCC950, which effectively reduces the synthesis of IL-1 $\beta$ in a disease model of multiple sclerosis [132], and could represent an effective tool to treat NLRP3-associated syndromes, such as autoinflammatory and autoimmune diseases [133]. Another compound, known as Andro, was tested in an experimental design in vivo and in an in vitro model of colon carcinogenesis, with the aim of establishing the effect of the NLRP3 inflammasome. It is worth noting that Andro acts as a trigger, promoting mitophagy in macrophages by inducing a decrease in membrane potential through the inactivation of the NLRP3 inflammasome [134].

The interest elicited by the effectiveness of this new class of drugs is supported by a growing body of data. Following the synthesis of compounds such as glyburide [135], which was the first molecule to be studied for its ability to prevent NLRP3 activation, albeit only at high doses in vivo, a number of similar molecules has been synthesized. Among these, 16673-34-0 (5-chloro-2-methoxy- $N$-[2-(4-sulfamoylphenyl)ethyl] benzamide), which was developed to limit the infarct size following myocardial ischemia-reperfusion in a mouse model, proved to be highly effective [136].

\section{Outstanding Questions}

Several studies have described how the oxidative damage of mitochondria and the activation of inflammasomes can interact to determine defects of the CP. Targeting these two mechanisms would be relevant both to curing rare disorders of cholesterol biosynthesis and to the treatment of metabolic and degenerative disorders. Although considerable evidence, deriving from cellular and animal models, is available, much remains to be understood about the real potential of inflammasome inhibitors in the clinical setting. The crucial fact remains that cholesterol is tightly regulated by positive and negative feedback mechanisms that may affect different cell types and functions in different ways.

For example, consistent data show that shortage of geranygeranyiol can lead to inflammation by reducing prenylation of membrane bound GTP-binding proteins of the Rab and Rac family, with consequent activation of the inflammasome [137-140]. However, recent data support the idea that also the shortage of cholesterol may exert an anti-inflammatory effect by reducing the substrate available to synthesize 25-hydroxycholesterol [141]. The matter becomes even more complicated if we consider that 25-hydroxycholesterol can regulate the enzymes of the pathway through modulation of transcription factors, the so-called sterol regulatory element-binding proteins (SREBPs), and thus affect the concentration of mevalonate-derived compounds.

Furthermore, the regulation of the $\mathrm{CP}$ may vary greatly depending on the cell type. $\mathrm{CP}$ plays an essential role in liver metabolism and in the production of biliary acids. In monocytes, the main function of the $\mathrm{CP}$ is probably to modulate the activity of membrane bound proteins or regulate cell membrane composition. Therefore, it is difficult to predict how pharmaceutical interventions on this pathway may influence the various functions of the different cells types and organs.

For the same reasons, it is hard to predict what the long term consequences of treatments that reduce the inflammatory response and hyper-protect mitochondria could be. Further studies addressing these questions in preclinical settings are needed. In the meantime, randomized controlled 
trials will definitely clarify the preventive and curative potential of these novel therapeutic strategies on neurodegenerative and cardiovascular inflammatory disorders.

Acknowledgments: This study was supported by a grant from the Institute for Maternal and Child Health-IRCCS “Burlo Garofolo"-Trieste, Italy (RC.: 02 14, Line: 3).

Author Contributions: Annalisa Marcuzzi, Liza Vecchi Brumatti, Alberto Tommasini, and Marina Zweyer conceived and wrote, revised and assembled the paper; Elisa Piscianz and Claudia Loganes wrote "The Cholesterol Pathway: A Pleiotropic Biochemical System"; Sabrine Bilel and Roberta Bortul wrote "Diseases Linked to the Deregulation of the CP"; Annalisa Marcuzzi and Alberto Tommasini wrote "Convergent Pathogenic Mechanisms on Deregulation of the Cholesterol Pathway"; Annalisa Marcuzzi and Liza Vecchi Brumatti wrote "Innovative Target Therapies Counteracting Inflammation Caused by Cholesterol Dysfunctions"; Alberto Tommasini wrote "Outstanding Questions"; and Alessandra Knowles revised the English version.

Conflicts of Interest: The authors declare no conflict of interest.

\section{References}

1. Goldstein, J.L.; Brown, M.S. Regulation of the mevalonate pathway. Nature 1990, 343, 425-430. [CrossRef] [PubMed]

2. Thurnher, M.; Gruenbacher, G.; Nussbaumer, O. Regulation of mevalonate metabolism in cancer and immune cells. Biochim. Biophys. Acta 2013, 1831, 1009-1015. [CrossRef] [PubMed]

3. Hinson, D.D.; Chambliss, K.L.; Toth, M.J.; Tanaka, R.D.; Gibson, K.M. Post-translational regulation of mevalonate kinase by intermediates of the cholesterol and nonsterol isoprene biosynthetic pathways. J. Lipid Res. 1997, 38, 2216-2223. [PubMed]

4. Ikeda, U.; Shimada, K. Pleiotropic effects of statins on the vascular tissue. Curr. Drug Targets Cardiovasc. Haematol. Disord. 2001, 1, 51-58. [CrossRef] [PubMed]

5. Jo, Y.; DeBose-Boyd, R.A. Control of cholesterol synthesis through regulated ER-associated degradation of HMG CoA reductase. Crit. Rev. Biochem. Mol. Biol. 2010, 45, 185-198. [CrossRef] [PubMed]

6. Nakanishi, M.; Goldstein, J.L.; Brown, M.S. Multivalent control of 3-hydroxy-3-methylglutaryl coenzyme A reductase. Mevalonate-derived product inhibits translation of mRNA and accelerates degradation of enzyme. J. Biol. Chem. 1988, 263, 8929-8937. [PubMed]

7. Hampton, R.; Dimster-Denk, D.; Rine, J. The biology of HMG-CoA reductase: The pros of contra-regulation. Trends Biochem. Sci. 1996, 21, 140-145. [CrossRef]

8. Crisby, M. Modulation of the inflammatory process by statins. Drugs Today 2003, 39, 137-143. [CrossRef] [PubMed]

9. Goldstein, J.L.; Brown, M.S. Progress in understanding the LDL receptor and HMG-CoA reductase, two membrane proteins that regulate the plasma cholesterol. J. Lipid Res. 1984, 25, 1450-1461. [PubMed]

10. Jira, P. Cholesterol metabolism deficiency. Handb. Clin. Neurol. 2013, 113, 1845-1850. [PubMed]

11. Marcuzzi, A.; Decorti, G.; Pontillo, A.; Ventura, A.; Tommasini, A. Decreased cholesterol levels reflect a consumption of anti-inflammatory isoprenoids associated with an impaired control of inflammation in a mouse model of mevalonate kinase deficiency. Inflamm. Res. 2010, 59, 335-338. [CrossRef] [PubMed]

12. Herman, G.E. Disorders of cholesterol biosynthesis: Prototypic metabolic malformation syndromes. Hum. Mol. Genet. 2003, 12, R75-R88. [CrossRef] [PubMed]

13. Marcuzzi, A.; Pontillo, A.; De Leo, L.; Tommasini, A.; Decorti, G.; Not, T.; Ventura, A. Natural isoprenoids are able to reduce inflammation in a mouse model of mevalonate kinase deficiency. Pediatr. Res. 2008, 64, 177-182. [CrossRef] [PubMed]

14. Mulders-Manders, C.M.; Simon, A. Hyper-IgD syndrome/mevalonate kinase deficiency: What is new? Semin. Immunopathol. 2015, 37, 371-376. [CrossRef] [PubMed]

15. Varret, M.; Abifadel, M.; Rabès, J.P.; Boileau, C. Genetic heterogeneity of autosomal dominant hypercholesterolemia. Clin. Genet. 2008, 73, 1-13. [CrossRef] [PubMed]

16. Van der Meer, J.W.; Vossen, J.M.; Radl, J.; van Nieuwkoop, J.A.; Meyer, C.J.; Lobatto, S.; van Furth, R. Hyperimmunoglobulinaemia D and periodic fever: A new syndrome. Lancet 1984, 1, 1087-1090. [CrossRef]

17. Drenth, J.P.; van der Meer, J.W. Hereditary periodic fever. N. Engl. J. Med. 2001, 345, 1748-1757. [CrossRef] [PubMed] 
18. Opitz, J.M.; Penchaszadeh, V.B.; Holt, M.C.; Spano, L.M. Smith-Lemli-Opitz (RSH) syndrome bibliography. Am. J. Med. Genet. 1987, 28, 745-750. [CrossRef] [PubMed]

19. Tint, G.S.; Irons, M.; Elias, E.R.; Batta, A.K.; Frieden, R.; Chen, T.S.; Salen, G. Defective cholesterol biosynthesis associated with the Smith-Lemli-Opitz syndrome. N. Engl. J. Med. 1994, 330, 107-113. [CrossRef] [PubMed]

20. Kelley, R.I. Inborn errors of cholesterol biosynthesis. Adv. Pediatr. 2000, 47, 1-53. [PubMed]

21. Platt, F.M.; Wassif, C.; Colaco, A.; Dardis, A.; Lloyd-Evans, E.; Bembi, B.; Porter, F.D. Disorders of cholesterol metabolism and their unanticipated convergent mechanisms of disease. Annu. Rev. Genom. Hum. Genet. 2014, 15, 173-194. [CrossRef] [PubMed]

22. Derry, J.M.; Gormally, E.; Means, G.D.; Zhao, W.; Meindl, A.; Kelley, R.I.; Boyd, Y.; Herman, G.E. Mutations in a delta $8-\Delta 7$ sterol isomerase in the tattered mouse and $\mathrm{X}$-linked dominant chondrodysplasia punctata. Nat. Genet. 1999, 22, 286-290. [CrossRef] [PubMed]

23. Falek, A.; Heath, C.W., Jr.; Ebbin, A.J.; McLean, W.R. Unilateral limb and skin deformities with congenital heart disease in two siblings: A lethal syndrome. J. Pediatr. 1968, 73, 910-913. [CrossRef]

24. Happle, R.; Koch, H.; Lenz, W. The CHILD syndrome. Congenital hemidysplasia with ichthyosiform erythroderma and limb defects. Eur. J. Pediatr. 1980, 134, 27-33. [CrossRef] [PubMed]

25. Greenberg, C.R.; Rimoin, D.L.; Gruber, H.E.; DeSa, D.J.; Reed, M.; Lachman, R.S. A new autosomal recessive lethal chondrodystrophy with congenital hydrops. Am. J. Med. Genet. 1988, 29, 623-632. [CrossRef] [PubMed]

26. Brunetti-Pierri, N.; Corso, G.; Rossi, M.; Ferrari, P.; Balli, F.; Rivasi, F.; Annunziata, I.; Ballabio, A.; Russo, A.D.; Andria, G.; et al. Lathosterolosis, a novel multiple-malformation/mental retardation syndrome due to deficiency of 3ß-hydroxysteroid- $\Delta 5$-desaturase. Am. J. Hum. Genet. 2002, 71, 952-958. [CrossRef] [PubMed]

27. FitzPatrick, D.R.; Keeling, J.W.; Evans, M.J.; Kan, A.E.; Bell, J.E.; Porteous, M.E.; Mills, K.; Winter, R.M.; Clayton, P.T. Clinical phenotype of desmosterolosis. Am. J. Med. Genet. 1998, 75, 145-152. [CrossRef]

28. Waterham, H.R.; Koster, J.; Romeijn, G.J.; Hennekam, R.C.; Vreken, P.; Andersson, H.C.; FitzPatrick, D.R.; Kelley, R.I.; Wanders, R.J. Mutations in the $3 \beta$-hydroxysterol $\Delta 24$-reductase gene cause desmosterolosis, an autosomal recessive disorder of cholesterol biosynthesis. Am. J. Hum. Genet. 2001, 69, 685-694. [CrossRef] [PubMed]

29. Tall, A.R.; Yvan-Charvet, L. Cholesterol, inflammation and innate immunity. Nat. Rev. Immunol. 2015, 15, 104-116. [CrossRef] [PubMed]

30. Martinon, F.; Burns, K.; Tschopp, J. The inflammasome: A molecular platform triggering activation of inflammatory caspases and processing of proIL- $\beta$. Mol. Cell 2002, 10, 417-426. [CrossRef]

31. Schroder, K.; Tschopp, J. The inflammasomes. Cell 2010, 140, 821-832. [CrossRef] [PubMed]

32. Lamkanfi, M. Emerging inflammasome effector mechanisms. Nat. Rev. Immunol. 2011, 11, $213-220$. [CrossRef] [PubMed]

33. Masters, S.L. Specific inflammasomes in complex diseases. Clin. Immunol. 2013, 147, 223-228. [CrossRef] [PubMed]

34. Faustin, B.; Lartigue, L.; Bruey, J.M.; Luciano, F.; Sergienko, E.; Bailly-Maitre, B.; Volkmann, N.; Hanein, D.; Rouiller, I.; Reed, J.C. Reconstituted NALP1 inflammasome reveals two-step mechanism of caspase-1 activation. Mol. Cell 2007, 25, 713-724. [CrossRef] [PubMed]

35. Minkiewicz, J.; de Rivero Vaccari, J.P.; Keane, R.W. Human astrocytes express a novel NLRP2 inflammasome. Glia 2013, 61, 1113-1121. [CrossRef] [PubMed]

36. Ozaki, E.; Campbell, M.; Doyle, S.L. Targeting the NLRP3 inflammasome in chronic inflammatory diseases: Current perspectives. J. Inflamm. Res. 2015, 8, 15-27. [PubMed]

37. Anand, P.K.; Malireddi, R.K.; Lukens, J.R.; Vogel, P.; Bertin, J.; Lamkanfi, M.; Kanneganti, T.D. NLRP6 negatively regulates innate immunity and host defence against bacterial pathogens. Nature 2012, 488, 389-393. [CrossRef] [PubMed]

38. Khare, S.; Dorfleutner, A.; Bryan, N.B.; Yun, C.; Radian, A.D.; de Almeida, L.; Rojanasakul, Y.; Stehlik, C. An NLRP7-containing inflammasome mediates recognition of microbial lipopeptides in human macrophages. Immunity 2012, 36, 464-476. [CrossRef] [PubMed]

39. Tuncer, S.; Fiorillo, M.T.; Sorrentino, R. The multifaceted nature of NLRP12. J. Leukoc. Biol. 2014, 96, 991-1000. [CrossRef] [PubMed]

40. Vance, R.E. The NAIP/NLRC4 inflammasomes. Curr. Opin. Immunol. 2015, 32, 84-89. [CrossRef] [PubMed] 
41. Haneklaus, M.; O'Neill, L.A. NLRP3 at the interface of metabolism and inflammation. Immunol. Rev. 2015, 265, 53-62. [CrossRef] [PubMed]

42. Zhou, R.; Yazdi, A.S.; Menu, P.; Tschopp, J. A role for mitochondria in NLRP3 inflammasome activation. Nature 2011, 469, 221-225. [CrossRef] [PubMed]

43. Bauernfeind, F.; Bartok, E.; Rieger, A.; Franchi, L.; Nunez, G.; Hornung, V. Cutting edge: Reactive oxygen species inhibitors block priming, but not activation, of the NLRP3 inflammasome. J. Immunol. 2011, 187, 613-617. [CrossRef] [PubMed]

44. Hornung, V.; Bauernfeind, F.; Halle, A.; Samstad, E.O.; Kono, H.; Rock, K.L.; Fitzgerald, K.A.; Latz, E. Silica crystals and aluminum salts activate the NALP3 inflammasome through phagosomal destabilization. Nat. Immunol. 2008, 8, 847-856. [CrossRef] [PubMed]

45. Hernandez-Cuellar, E.; Tsuchiya, K.; Hara, H.; Fang, R.; Sakai, S.; Kawamura, I.; Akira, S.; Mitsuyama, M. Cutting edge: Nitric oxide inhibits the NLRP3 inflammasome. J. Immunol. 2012, 189, 5113-5117. [CrossRef] [PubMed]

46. Caito, S.W.; Aschner, M. Mitochondrial redox dysfunction and environmental exposures. Antioxid. Redox Signal. 2015. [CrossRef] [PubMed]

47. Sorriento, D.; Pascale, A.V.; Finelli, R.; Carillo, A.L.; Annunziata, R.; Trimarco, B.; Iaccarino, G. Targeting mitochondria as therapeutic strategy for metabolic disorders. Sci. World J. 2014, 2014, 604685. [CrossRef] [PubMed]

48. Dikalov, S.I.; Ungvari, Z. Role of mitochondrial oxidative stress in hypertension. Am. J. Physiol. Heart Circ. Physiol. 2013, 305, H1417-H1427. [CrossRef] [PubMed]

49. Münzel, T.; Gori, T.; Bruno, R.M.; Taddei, S. Is oxidative stress a therapeutic target in cardiovascular disease? Eur. Heart J. 2010, 22, 2741-2748. [CrossRef] [PubMed]

50. Shen, G.X. Mitochondrial dysfunction, oxidative stress and diabetic cardiovascular disorders. Cardiovasc. Hematol. Disord. Drug Targets 2012, 12, 106-112. [CrossRef] [PubMed]

51. Mercer, J.R.; Cheng, K.K.; Figg, N.; Gorenne, I.; Mahmoudi, M.; Griffin, J.; Vidal-Puig, A.; Logan, A.; Murphy, M.P.; Bennett, M. DNA damage links mitochondrial dysfunction to atherosclerosis and the metabolic syndrome. Circ. Res. 2010, 107, 1021-1031. [CrossRef] [PubMed]

52. Madamanchi, N.R.; Runge, M.S. Mitochondrial dysfunction in atherosclerosis. Circ. Res. 2007, 100, 460-473. [CrossRef] [PubMed]

53. Vercesi, A.E.; Castilho, R.F.; Kowaltowski, A.J.; Oliveira, H.C. Mitochondrial energy metabolism and redox state in dyslipidemias. IUBMB Life 2007, 59, 263-268. [CrossRef] [PubMed]

54. Clendening, J.W.; Pandyra, A.; Boutros, P.C.; el Ghamrasni, S.; Khosravi, F.; Trentin, G.A.; Martirosyan, A.; Hakem, A.; Hakem, R.; Jurisica, I.; et al. Dysregulation of the mevalonate pathway promotes transformation. Proc. Natl. Acad. Sci. USA 2010, 107, 15051-15056. [CrossRef] [PubMed]

55. Vance, J.E. Dysregulation of cholesterol balance in the brain: Contribution to neurodegenerative diseases. Dis. Model. Mech. 2012, 6, 746-755. [CrossRef] [PubMed]

56. Van der Burgh, R.; Boes, M. Mitochondria in autoinflammation: Cause, mediator or bystander? Trends Endocrinol. Metab. 2015, 26, 263-271. [CrossRef] [PubMed]

57. Poillet-Perez, L.; Despouy, G.; Delage-Mourroux, R.; Boyer-Guittaut, M. Interplay between ROS and autophagy in cancer cells, from tumor initiation to cancer therapy. Redox Biol. 2015, 4, 184-192. [CrossRef] [PubMed]

58. Venditti, P.; di Stefano, L.; di Meo, S. Mitochondrial metabolism of reactive oxygen species. Mitochondrion 2013, 13, 71-82. [CrossRef] [PubMed]

59. Elmore, S. Apoptosis: A review of programmed cell death. Toxicol. Pathol. 2007, 35, 495-516. [CrossRef] [PubMed]

60. Nuñez, G.; Benedict, M.A.; Hu, Y.; Inohara, N. Caspases: The proteases of the apoptotic pathway. Oncogene 1998, 17, 3237-3245. [CrossRef] [PubMed]

61. Nakahira, K.; Haspel, J.A.; Rathinam, V.A.; Lee, S.J.; Dolinay, T.; Lam, H.C.; Englert, J.A.; Rabinovitch, M.; Cernadas, M.; Kim, H.P.; et al. Autophagy proteins regulate innate immune responses by inhibiting the release of mitochondrial DNA mediated by the NALP3 inflammasome. Nat. Immunol. 2011, 12, 222-230. [CrossRef] [PubMed] 
62. Tricarico, P.M.; Marcuzzi, A.; Piscianz, E.; Monasta, L.; Crovella, S.; Kleiner, G. Mevalonate kinase deficiency and neuroinflammation: Balance between apoptosis and pyroptosis. Int. J. Mol. Sci. 2013, 14, 23274-23288. [CrossRef] [PubMed]

63. Marcuzzi, A.; Tricarico, P.M.; Piscianz, E.; Kleiner, G.; Vecchi Brumatti, L.; Crovella, S. Lovastatin induces apoptosis through the mitochondrial pathway in an undifferentiated SH-SY5Y neuroblastoma cell line. Cell Death Dis. 2013, 4, e585. [CrossRef] [PubMed]

64. Li, Z.Y.; Yang, Y.; Ming, M.; Liu, B. Mitochondrial ROS generation for regulation of autophagic pathways in cancer. Biochem. Biophys. Res. Commun. 2011, 414, 5-8. [CrossRef] [PubMed]

65. Wang, K.; Klionsky, D.J. Mitochondria removal by autophagy. Autophagy 2011, 7, 297-300. [CrossRef] [PubMed]

66. Lazarou, M. Keeping the immune system in check: a role for mitophagy. Immunol. Cell Biol. 2015, 93, 3-10. [CrossRef] [PubMed]

67. Braschi, E.; McBride, H.M. Mitochondria and the culture of the Borg: Understanding the integration of mitochondrial function within the reticulum, the cell, and the organism. Bioessays 2010, 32, 958-966. [CrossRef] [PubMed]

68. Patergnani, S.; Pinton, P. Mitophagy and mitochondrial balance. Methods Mol. Biol. 2015, 1241, $181-194$. [PubMed]

69. Choi, A.M.; Ryter, S.W.; Levine, B. Autophagy in human health and disease. N. Engl. J. Med. 2013, 368, 651-662. [CrossRef] [PubMed]

70. Chang, S.; Ren, G.; Steiner, R.D.; Merkens, L.; Roullet, J.B.; Korade, Z.; DiMuzio, P.J.; Tulenko, T.N. Elevated autophagy and mitochondrial dysfunction in the Smith-Lemli-Opitz Syndrome. Mol. Genet. Metab. Rep. 2014, 1, 431-442. [CrossRef] [PubMed]

71. Van der Burgh, R.; Pervolaraki, K.; Turkenburg, M.; Waterham, H.R.; Frenkel, J.; Boes, M. Unprenylated RhoA contributes to IL-1 $\beta$ hypersecretion in mevalonate kinase deficiency model through stimulation of Rac1 activity. J. Biol. Chem. 2014, 289, 27757-27765. [CrossRef] [PubMed]

72. Van der Burgh, R.; Nijhuis, L.; Pervolaraki, K.; Compeer, E.B.; Jongeneel, L.H.; van Gijn, M.; Coffer, P.J.; Murphy, M.P.; Mastroberardino, P.G.; Frenkel, J.; et al. Defects in mitochondrial clearance predispose human monocytes to interleukin-1 $\beta$ hypersecretion. J. Biol. Chem. 2014, 289, 5000-5012. [CrossRef] [PubMed]

73. Marcuzzi, A.; Crovella, S.; Monasta, L.; Vecchi Brumatti, L.; Gattorno, M.; Frenkel, J. Mevalonate kinase deficiency: Disclosing the role of mevalonate pathway modulation in inflammation. Curr. Pharm. Des. 2012, 18, 5746-5752. [CrossRef] [PubMed]

74. Williams, D.; Feely, J. Pharmacokinetic-pharmacodynamic drug interactions with HMG-CoA reductase inhibitors. Clin. Pharmacokinet. 2002, 41, 343-370. [CrossRef] [PubMed]

75. Endo, A. The discovery and development of HMG-CoA reductase inhibitors. J. Lipid Res. 1992, 33, 1569-1582. [CrossRef] [PubMed]

76. Ghavami, S; Yeganeh, B.; Stelmack, G.L.; Kashani, H.H.; Sharma, P.; Cunnington, R.; Rattan, S.; Bathe, K.; Klonisch, T.; Dixon, I.M.; et al. Apoptosis, autophagy and ER stress in mevalonate cascade inhibition-induced cell death of human atrial fibroblasts. Cell Death Dis. 2012, 3, e330. [CrossRef]

77. Stone, N.J. Current drug treatments for lipid management. Manag. Care 2002, 9S, 4-9.

78. Bandeali, S.J.; Daye, J.; Virani, S.S. Novel therapies for treating familial hypercholesterolemia. Curr. Atheroscler. Rep. 2014, 16, 382. [CrossRef] [PubMed]

79. Fordyce, C.B.; Roe, M.T.; Ahmad, T.; Libby, P.; Borer, J.S.; Hiatt, W.R.; Bristow, M.R.; Packer, M.; Wasserman, S.M.; Braunstein, N.; et al. Cardiovascular drug development: Is it dead or just hibernating? J. Am. Coll. Cardiol. 2015, 65, 1567-1582. [CrossRef] [PubMed]

80. Šimić, I.; Reiner, Ž. Adverse effects of statins-Myths and reality. Curr. Pharm. Des. 2015, 21, 1220-1226. [CrossRef] [PubMed]

81. Pirillo, A.; Catapano, A.L. Statin intolerance: Diagnosis and remedies. Curr. Cardiol. Rep. 2015, $17,27$. [CrossRef] [PubMed]

82. Apostolopoulou, M.; Corsini, A.; Roden, M. The role of mitochondria in statin-induced myopathy. Eur. J. Clin. Investig. 2015, 45, 745-754. [CrossRef] [PubMed]

83. Izadpanah, R.; Schächtele, D.J.; Pfnür, A.B.; Lin, D.; Slakey, D.P.; Kadowitz, P.J.; Alt, E.U. The impact of statins on biological characteristics of stem cells provides a novel explanation for their pleotropic beneficial and adverse clinical effects. Am. J. Physiol. Cell Physiol. 2015. [CrossRef] [PubMed] 
84. Luckman, S.P.; Hughes, D.E.; Coxon, F.P.; Graham, R.; Russell, G.; Rogers, M.J. Nitrogen-containing bisphosphonates inhibit the mevalonate pathway and prevent post-translational prenylation of GTP-binding proteins, including Ras. J. Bone Miner. Res. 1998, 13, 581-589. [CrossRef] [PubMed]

85. Rogers, M.J. New insights into the molecular mechanisms of action of bisphosphonates. Curr. Pharm. Des. 2003, 9, 2643-2658. [CrossRef] [PubMed]

86. Russell, R.G. Bisphosphonates: the first 40 years. Bone 2011, 1, 2-19. [CrossRef] [PubMed]

87. Merrella, M.A.; Wakchourea, S.; Lehenkarib, P.P.; Harrisa, K.W.; Selander, K.S. Inhibition of the mevalonate pathway and activation of 38 MAP kinase are independently regulated by nitrogen-containing bisphosphonates in breast cancer cells. Eur. J. Pharmacol. 2007, 570, 27-37. [CrossRef] [PubMed]

88. Frith, J.C.; Monkkonen, J.; Blackburn, G.M.; Russell, R.G.; Rogers, M.J. Clodronate and liposome-encapsulated clodronate are metabolized to a toxic ATP analog, adenosine $5^{\prime}-(\beta, \gamma$-dichloromethylene $)$ triphosphate, by mammalian cells in vitro. J. Bone Miner. Res. 1997, 12, 1358-1367. [CrossRef] [PubMed]

89. Lehenkari, P.P.; Kellinsalmi, M.; Näpänkangas, J.P.; Ylitalo, K.V.; Mönkkönen, J.; Rogers, M.J.; Azhayev, A.; Väänänen, H.K.; Hassinen, I.E. Further insight into mechanism of action of clodronate: Inhibition of mitochondrial ADP/ATP translocase by a nonhydrolyzable, adenine-containing metabolite. Mol. Pharmacol. 2002, 5, 1255-1262. [CrossRef]

90. Diel, I.J.; Bergner, R.; Grötz, K.A. Adverse effects of bisphosphonates: Current issues. J. Support. Oncol. 2007, 5, 475-482. [PubMed]

91. Chang, J.T.; Green, L.; Beitz, J. Renal failure with the use of zoledronic acid. N. Engl. J. Med. 2003, 349, 1676-1678. [PubMed]

92. Bergner, R.; Diel, I.J.; Henrich, D.; Hoffmann, M.; Uppenkamp, M. Differences in nephrotoxicity of intravenous bisphosphonates for the treatment of malignancy-related bone disease. Onkologie 2006, 29, 534-540. [CrossRef] [PubMed]

93. Pecherstorfer, M.; Jilch, R.; Sauty, A.; Horn, E.; Keck, A.V.; Zimmer-Roth, I.; Thiebaud, D. Effect of first treatment with aminobisphosphonates pamidronate and ibandronate on circulating lymphocyte subpopulations. J. Bone Miner. Res. 2000, 15, 147-154. [CrossRef] [PubMed]

94. Thiébaud, D.; Sauty, A.; Burckhardt, P.; Leuenberger, P.; Sitzler, L.; Green, J.R.; Kandra, A.; Zieschang, J.; Ibarra de Palacios, P. An in vitro and in vivo study of cytokines in the acute-phase response associated with bisphosphonates. Calcif. Tissue Int. 1997, 61, 386-392. [PubMed]

95. Rosen, L.S.; Gordon, D.; Tchekmedyian, N.S.; Yanagihara, R.; Hirsh, V.; Krzakowski, M.; Pawlicki, M.; de Souza, P.; Zheng, M.; Urbanowitz, G.; et al. Long-term efficacy and safety of zoledronic acid in the treatment of skeletal metastases in patients with nonsmall cell lung carcinoma and other solid tumors: A randomized, Phase III, double-blind, placebo-controlled trial. Cancer 2004, 100, 2613-2621. [CrossRef] [PubMed]

96. Dicuonzo, G.; Vincenzi, B.; Santini, D.; Avvisati, G.; Rocci, L.; Battistoni, F.; Gavasci, M.; Borzomati, D.; Coppola, R.; Tonini, G. Fever after zoledronic acid administration is due to increase in TNF- $\alpha$ and IL-6. J. Interferon Cytokine Res. 2003, 23, 649-654. [CrossRef] [PubMed]

97. Thompson, K.; Rogers, M.J. Statins prevent bisphosphonate induced $\gamma, \Delta$-T-cell proliferation and activation in vitro. J. Bone Miner. Res. 2004, 19, 278-288. [CrossRef] [PubMed]

98. Marshall, J.K. The gastrointestinal tolerability and safety of oral bisphosphonates. Expert Opin. Drug Saf. 2002, 1, 71-78. [CrossRef] [PubMed]

99. Migliorati, C.A.; Casiglia, J.; Epstein, J.; Jacobsen, P.L.; Siegel, M.A.; Woo, S.B. Managing the care of patients with bisphosphonate-associated osteonecrosis: An American academy of oral medicine position paper. J. Am. Dent. Assoc. 2005, 136, 1658-1668.

100. Elsayed, R.K.; Evans, J.D. Emerging lipid-lowering drugs: Squalene synthase inhibitors. Expert Opin. Emerg. Drugs 2008, 13, 309-322. [CrossRef] [PubMed]

101. Liao, J.K. Squalene synthase inhibitor lapaquistat acetate: Could anything be better than statins? Circulation 2011, 123, 1925-1928. [CrossRef] [PubMed]

102. Mo, H.; Elson, C.E. Studies of the isoprenoid-mediated inhibition of mevalonate synthesis applied to cancer chemotherapy and chemoprevention. Exp. Biol. Med. 2004, 229, 567-585.

103. Marcuzzi, A.; de Leo, L.; Decorti, G.; Crovella, S.; Tommasini, A.; Pontillo, A. The farnesyltransferase inhibitors tipifarnib and lonafarnib inhibit cytokines secretion in a cellular model of mevalonate kinase deficiency. Pediatr. Res. 2011, 70, 78-82. [CrossRef] [PubMed] 
104. Olszewska, A.; Szewczyk, A. Mitochondria as a pharmacological target: Magnum overview. IUBMB Life 2013, 65, 273-281. [CrossRef] [PubMed]

105. Cochemé, H.M.; Kelso, G.F.; James, A.M.; Ross, M.F.; Trnka, J.; Mahendiran, T.; Asin-Cayuela, J.; Blaikie, F.H.; Manas, A.R.; Porteous, C.M.; et al. Mitochondrial targeting of quinones: Therapeutic implications. Mitochondrion 2007, S94-S102. [CrossRef] [PubMed]

106. Dhanasekaran, A.; Kotamraju, S.; Kalivendi, S.V.; Matsunaga, T.; Shang, T.; Keszler, A.; Joseph, J.; Kalyanaraman, B. Supplementation of endothelial cells with mitochondria-targeted antioxidants inhibit peroxide-induced mitochondrial iron uptake, oxidative damage, and apoptosis. J. Biol. Chem. 2004, 279, 37575-37587. [CrossRef] [PubMed]

107. Smith, R.A.; Porteous, C.M.; Coulter, C.V.; Murphy, M.P. Selective targeting of an antioxidant to mitochondria. Eur. J. Biochem. 1999, 263, 709-716. [CrossRef] [PubMed]

108. Reddy, P.H. Mitochondrial oxidative damage in aging and Alzheimer's disease: Implications for mitochondrially targeted antioxidant therapeutics. J. Biomed. Biotechnol. 2006, 3, 31372. [CrossRef] [PubMed]

109. Kelso, G.F.; Porteous, C.M.; Coulter, C.V.; Hughes, G.; Porteous, W.K.; Ledgerwood, E.C.; Smith, R.A.; Murphy, M.P. Selective targeting of a redox-active ubiquinone to mitochondria within cells: Antioxidant and antiapoptotic properties. J. Biol Chem. 2001, 276, 4588-4596. [CrossRef] [PubMed]

110. Hwang, P.M.; Bunz, F.; Yu, J.; Rago, C.; Chan, T.A.; Murphy, M.P.; Kelso, G.F.; Smith, R.A.; Kinzler, K.W.; Vogelstein, B. Ferredoxin reductase affects p53-dependent, 5-fluorouracil-induced apoptosis in colorectal cancer cells. Nat. Med. 2001, 7, 1111-1117. [CrossRef] [PubMed]

111. Saretzki, G.; Murphy, M.P.; von Zglinicki, T. MitoQ counteracts telomere shortening and elongates lifespan of fibroblasts under mild oxidative stress. Aging Cell 2003, 2, 141-143. [CrossRef] [PubMed]

112. Schafer, M.; Schafer, C.; Ewald, N.; Piper, H.M.; Noll, T. Role of redox signaling in the autonomous proliferative response of endothelial cells to hypoxia. Circ. Res. 2003, 92, 1010-1015. [CrossRef] [PubMed]

113. Barhoumi, R.; Faske, J.; Liu, X.; Tjalkens, R.B. Manganese potentiates lipopolysaccharide-induced expression of NOS2 in C6 glioma cells through mitochondrial-dependent activation of nuclear factor kB. Brain Res. Mol. Brain Res. 2004, 122, 167-179. [CrossRef] [PubMed]

114. Kalivendi, S.V.; Konorev, E.A.; Cunningham, S.; Vanamala, S.K.; Kaji, E.H.; Joseph, J.; Kalyanaraman, B. Doxorubicin activates nuclear factor of activated T-lymphocytes and Fas ligand transcription: Role of mitochondrial reactive oxygen species and calcium. Biochem. J. 2005, 389, 527-539. [CrossRef] [PubMed]

115. Koopman, W.J.; Verkaart, S.; Visch, H.J.; van der Westhuizen, F.H.; Murphy, M.P.; van den Heuvel, L.W.; Smeitink, J.A.; Willems, P.H. Inhibition of complex I of the electron transport chain causes view the MathML sourceO2-Mediated mitochondrial outgrowth. Am. J. Physiol. Cell Physiol. 2005, 288, C1440-C1450. [CrossRef] [PubMed]

116. Pletjushkina, O.Y.; Fetisova, E.K.; Lyamzaev, K.G.; Ivanova, O.Y.; Domnina, L.V.; Vyssokikh, M.Y.; Pustovidko, A.V.; Vasiliev, J.M.; Murphy, M.P.; Chernyak, B.V.; et al. Long-distance apoptotic killing of cells is mediated by hydrogen peroxide in a mitochondrial ROS-dependent fashion. Cell Death Differ. 2005, 12, 1442-1444. [CrossRef] [PubMed]

117. Siler-Marsiglio, K.I.; Pan, Q.; Paiva, M.; Madorsky, I.; Khurana, N.C.; Heaton, M.B. Mitochondrially targeted vitamin $\mathrm{E}$ and vitamin $\mathrm{E}$ mitigate ethanol-mediated effects on cerebellar granule cell antioxidant defense systems. Brain Res. 2005, 1052, 202-211. [CrossRef] [PubMed]

118. Ross, M.F.; Kelso, G.F.; Blaikie, F.H.; James, A.M.; Cocheme, H.M.; Filipovska, A.; da Ros, T.; Hurd, T.R.; Smith, R.A.; Murphy, M.P. Lipophilic triphenylphosphonium cations as tools in mitochondrial bioenergetics and free radical biology. Biochemistry 2005, 70, 222-230. [CrossRef] [PubMed]

119. Crane, F.L. Hydroquinone dehydrogenases. Annu. Rev. Biochem. 1977, 46, 439-469. [CrossRef] [PubMed]

120. Kagan, V.E.; Serbinova, E.A.; Stoyanovsky, D.A.; Khwaja, S.; Packer, L. Assay of ubiquinones and ubiquinols as antioxidants. Methods Enzymol. 1994, 234, 343-354. [PubMed]

121. Maguire, J.J.; Wilson, D.S.; Packer, L. Mitochondrial electron transport-linked tocopheroxyl radical reduction. J. Biol. Chem. 1989, 264, 21462-21465. [PubMed]

122. Ernster, L.; Forsmark, P.; Nordenbrand, K. The mode of action of lipid-soluble antioxidants in biological membranes: Relationship between the effects of ubiquinol and vitamin $\mathrm{E}$ as inhibitors of lipid peroxidation in submitochondrial particles. BioFactors 1992, 3, 241-248. [CrossRef] [PubMed] 
123. Ingold, K.U.; Bowry, V.W.; Stocker, R.; Walling, C. Autoxidation of lipids and antioxidation by $\alpha$-tocopherol and ubiquinol in homogeneous solution and in aqueous dispersions of lipids: Unrecognized consequences of lipid particle size as exemplified by oxidation of human low density lipoprotein. Proc. Natl. Acad. Sci. USA 1993, 90, 45-49. [CrossRef] [PubMed]

124. Jauslin, M.L.; Meier, T.; Smith, R.A.; Murphy, M.P. Mitochondria targeted antioxidants protect Friedreich Ataxia fibroblasts from endogenous oxidative stress more effectively than untargeted antioxidants. FASEB J. 2003, 17, 1972-1974. [CrossRef] [PubMed]

125. Bedogni, B.; Pani, G.; Colavitti, R.; Riccio, A.; Borrello, S.; Murphy, M.; Smith, R.; Eboli, M.L.; Galeotti, T. Redox regulation of cAMP-responsive element-binding protein and induction of manganous superoxide dismutase in nerve growth factordependent cell survival. J. Biol. Chem. 2003, 278, 16510-16519. [CrossRef] [PubMed]

126. Paradies, G.; Petrosillo, G.; Pistolese, M.; di Venosa, N.; Federici, A.; Ruggiero, F.M. Decrease in mitochondrial complex I activity in ischemic/reperfused rat heart: involvement of reactive oxygen species and cardiolipin. Circ. Res. 2004, 94, 53-59. [CrossRef] [PubMed]

127. Smith, R.A.; Porteous, C.M.; Gane, A.M.; Murphy, M.P. Delivery of bioactive molecules to mitochondria in vivo. Proc. Natl. Acad. Sci. USA 2003, 100, 5407-5412. [CrossRef] [PubMed]

128. Adlam, V.J.; Harrison, J.C.; Porteous, C.M.; James, A.M.; Smith, R.A.; Murphy, M.P.; Sammut, I.A. Targeting an antioxidant to mitochondria decreases cardiac ischemia reperfusion injury. FASEB J. 2005, 19, 1088-1095. [CrossRef] [PubMed]

129. Duan, S.B.; Yang, S.K.; Zhou, Q.Y.; Pan, P.; Zhang, H.; Liu, F.; Xu, X.Q. Mitochondria-targeted peptides prevent on contrast-induced acute kidney injury in the rats with hypercholesterolemia. Ren. Fail. 2013, 35, 1124-1129. [CrossRef] [PubMed]

130. Dai, D.F.; Chiao, Y.A.; Marcinek, D.J.; Szeto, H.H.; Rabinovitch, P.S. Mitochondrial oxidative stress in aging and healthspan. Longev. Healthspan 2014, 1, 3-6. [CrossRef] [PubMed]

131. McCormack, W.J.; Parker, A.E.; O'Neill, L.A. Toll-like receptors and NOD-like receptors in rheumatic diseases. Arthritis Res. Ther. 2009, 11, 243. [CrossRef] [PubMed]

132. Coll, R.C.; Robertson, A.A.; Chae, J.J.; Higgins, S.C.; Muñoz-Planillo, R.; Inserra, M.C.; Vetter, I.; Dungan, L.S.; Monks, B.G.; Stutz, A.; et al. A small-molecule inhibitor of the NLRP3 inflammasome for the treatment of inflammatory diseases. Nat. Med. 2015, 21, 248-255. [PubMed]

133. Carta, S.; Penco, F.; Lavieri, R.; Martini, A.; Dinarello, C.A.; Gattorno, M.; Rubartelli, A. Cell stress increases ATP release in NLRP3 inflammasome-mediated autoinflammatory diseases, resulting in cytokine imbalance. Proc. Natl. Acad. Sci. USA 2015, 112, 2835-2840. [CrossRef] [PubMed]

134. Guo, W.; Sun, Y.; Liu, W.; Wu, X.; Guo, L.; Cai, P.; Wu, X.; Wu, X.; Shen, Y.; Shu, Y.; et al. Small molecule-driven mitophagy-mediated NLRP3 inflammasome inhibition is responsible for the prevention of colitis-associated cancer. Autophagy 2014, 10, 972-985. [CrossRef] [PubMed]

135. Lamkanfi, M.; Mueller, J.L.; Vitari, A.C.; Misaghi, S.; Fedorova, A.; Deshayes, K.; Lee, W.P.; Hoffman, H.M.; Dixit, V.M. Glyburide inhibits the Cryopyrin/Nalp3 inflammasome. J. Cell. Biol. 2009, 187, 61-70. [CrossRef] [PubMed]

136. Marchetti, C.; Chojnacki, J.; Toldo, S.; Mezzaroma, E.; Tranchida, N.; Rose, S.W.; Federici, M.; Van Tassell, B.W.; Zhang, S.; Abbate, A. A novel pharmacologic inhibitor of the NLRP3 inflammasome limits myocardial injury after ischemia-reperfusion in the mouse. J. Cardiovasc. Pharmacol. 2014, 63, 316-322. [CrossRef] [PubMed]

137. Huang, K.C.; Chen, C.W.; Chen, J.C.; Lin, W.W. HMG-CoA reductase inhibitors inhibit inducible nitric oxide synthase gene expression in macrophages. J. Biomed. Sci. 2003, 10, 396-405. [CrossRef] [PubMed]

138. Novelli, G.; D’Apice, M.R. Protein farnesylation and disease. J. Inherit. Metab. Dis. 2012, 35, 917-926. [CrossRef] [PubMed]

139. McTaggart, S.J. Isoprenylated proteins. Cell. Mol. Life Sci. 2006, 63, 255-267. [CrossRef] [PubMed]

140. Rikitake, Y.; Liao, J.K. Rho GTPases, statins, and nitric oxide. Circ. Res. 2005, 97, 1232-1235. [CrossRef] [PubMed]

141. Simon, A. Cholesterol metabolism and immunity. N. Engl. J. Med. 2014, 371, 1933-1935. [PubMed]

(C) 2015 by the authors; licensee MDPI, Basel, Switzerland. This article is an open access article distributed under the terms and conditions of the Creative Commons by Attribution (CC-BY) license (http:/ / creativecommons.org/licenses/by/4.0/). 